\title{
State or Regime? The Impact of Institutions on Welfare Outcomes
}

\author{
Simone Dietrich \\ Assistant Professor \\ Department of Political Science \\ University of Missouri \\ dietrich.simone@gmail.com \\ Michael Bernhard \\ Raymond and Miriam Ehrlich Eminent Scholar Chair \\ Department of Political Science \\ University of Florida \\ bernhard@ufl.edu
}

\section{Introduction}

Early research on "modernization" posited that democracy posed a barrier to development because the demands of citizens would overburden the state (De Schweinitz 1964; Huntington 1968; Chirot 1977). Since the transformation of a large number of dictatorships into democracies beginning in the mid-1970s, democracy has come to be seen not only as being a good in itself, but as a promoter of other positive outcomes - economic growth, egalitarian income distribution, and general welfare. In this paper, we concern ourselves with welfare outcomes while acknowledging that there is a large and complex literature on democracy and economic performance (Gerring, et al 2005; Barro 1998; and Baum and Lake 2003).

The widespread assumption is that democratic elites need to be responsive to the material conditions of the electorate, fearing that dissatisfaction will turn into electoral rejection. This is strongly congruent with median voter theory and the distributive theory of democracy (Meltzer and Richard 1981; Boix 2003; Acemoglu and Robinson 2006). There is also substantial empirical evidence that democracy distributes more to its citizens. The findings are robust across sev- 
eral different outcomes including welfare spending (Brown and Hunter 1999; Lake and Baum 2001; Rudra and Haggard 2005; Huber, Mustillo, and Stephens 2008), education (Brown and Hunter 2000; Stasavage 2005), and public health (Besley and Kudamatsu 2006; Wigley and Akkoyunlu-Wigley 2011a and 2011b). Przeworski et al. (2000) treat the subject more expansively, presenting evidence that once democracies and dictatorships reach a developmental threshold, different patterns of production, consumption, and investment lead to superior welfare outcomes in democracies.

There have been some dissenting voices, particularly with regard to the developing world. Kaufman and Segura-Ubiergo (2001) and Rudra (2002) have argued that globalization creates downward pressure on social spending. Haggard and Kaufman (2008) and Karakoc (2010) have highlighted the importance of authoritarian legacies as an important determinant of social spending in new democracies, and Keefer (2007) and Karakoc (2010) have noted how electoral concerns lead to spending targeted at organized political constituencies rather than broad welfare spending. Finally, and perhaps most damaging in its ramifications for the theory of superior democratic welfare outcomes, Ross (2006) claims that the relationship between democracy and human development is a product of sample bias. He argues that the regressions used in cross-national studies over-represent poorly performing authoritarianism and richer democracies, omitting economically successful authoritarian regimes.

In this paper, we question whether the difference between democracy and dictatorship is the most consequential institutional factor in the provision of welfare. We think that there is another crucial institutional dimension that has been omitted from the debate - state structures. Furthermore, we believe that earlier work that attempted to establish the basis for effective human development may have found a positive association with democracy because, on balance, 
democracies have more effective state structures than dictatorships. The absence of any attempt to capture the impact of the state may mean that this literature suffers from omitted variable bias.

In the discussion that follows, we present a rationale for why inclusion of the state in consideration of welfare outcomes is important. We lay out a specific set of tests that link specific capacities of the state, the maintenance of law and order and effective bureaucracy, to specific welfare outcomes -- infant mortality, food supply, and primary education. The results of those tests, performed on a large cross-section of developing countries over an extensive period of time, show that whereas democracy is inconsistently relevant to those outcomes, specific facets of state capacity play an important role for two of these three outcomes.

\section{State, Regime, and Welfare Outcomes}

Before we engage in a discussion about the state and its potential contribution to welfare outcomes, it is useful to distinguish between the state and regime, and to specify more clearly the ways in which state power is relevant. We understand regime-type as the form that rule takes. Specifically, regime characterizes who rules and the procedures by which they rule. Democracy and the large number of varieties of dictatorship differ from each other in the ways in which they select leadership, and the rules by which those leaders exercise power. We understand the state as the set of apparatuses that rulers have at their disposal to implement their policy choices. We look at two dimensions highlighted by Weber in his foundational work on states, the ability of rulers to maintain order and to direct the bureaucracy to put their chosen policies into practice with the desired result (1978). With these preliminary definitional issues out of the way, we can now return to relative merits of state and regime in explaining welfare outcomes.

Uniformly, the statistical tests about the impact of democracy on welfare outcomes reviewed in the introduction have not included the state as a potential causal factor. Whereas Ross 
(2006) has asserted that sample bias may account for the inconsistent findings on regime-type and welfare outcomes, we suggest that the absence of the state, a form of omitted variable bias, may well also account for the inconsistencies. Omission of the state from welfare outcome regressions would thus make it easier to attain significant findings for democracy, suggesting omitted variable bias. ${ }^{1}$

We are hardly the first to argue that the state is a central actor in development. Weber, the social theorist who frames our understanding of the modern state, was among the first to highlight the impact of a rational-legal bureaucracy on economic development. He argued that it was the only kind of administration that is compatible with capitalist development: "Today it is primarily the capitalist market economy which demands that the official business of public administration be discharged precisely, unambiguously, continuously, and with as much speed as possible" (1978: 974). Specifically, an officialdom with high levels of expertise operating in a framework of rational law promoted prosperity $(1981: 339 ; 1946: 87-88)$. This stands in marked contrast to patrimonial forms of rule where officials are not experts and not bound by a rational legal framework, but are instead notables bound by obedience to the ruler and traditional obligations to subordinates and peers (1978: ch. 12).

Gerschenkron (1962) popularized the idea that late developers relied on "state-guided industrialization" as a way of overcoming the "relative backwardness" that constrained their actions in relation to countries that had industrialized earlier. In "late developers," the state has often taken a proactive role in both the earlier phases of import substitution industrialization by

${ }^{1}$ The correlation between the law and order variable we use in analysis is positive but not overwhelmingly strong $(0.28)$. It is somewhat higher for the bureaucratic quality variable $(0.46)$. 
insulating domestic markets (Hirschman 1968; O’Donnell 1973) and later in regulating labor, and promoting investment and sectoral concentration in ways that opened "pathways from the periphery" via export-oriented growth strategies (Wade 1990; Haggard 1990; Evans 1995; Amsden 2001; Kohli 2004).

Economists concerned with development have introduced a number of political factors including dimensions of state capacity into the discussion of what promotes positive economic and human development outcomes through the study of "governance." A growing body of work has used the indicators Kaufmann et al. (1999) formulated for the World Bank to show that a range of political factors have salutary effects for development including welfare outcomes (Kaufmann et al. 1999; Mauro 1995; Rodrik 1997; Chong and Calderon 2000; Khan 2006).

Welfare outcomes are the product of both allocation by markets and administration, which is routinely carried out through bureaucracies (Easton 1953). ${ }^{2}$ The state plays a crucial role in both, setting the framework in which markets operate and directly as the primary instrument of administrative allocation. Where the state does a poor job of regulating markets, welfare will deteriorate in those areas where positive outcomes depend on markets. Where bureaucracies are ineffective, welfare tasks identified by the leadership of the state that require administrative means will not be effectively accomplished. We will thus highlight variables in our analysis that get at the impact of the state on the market and which gauge its bureaucratic effectiveness.

${ }^{2}$ In traditional societies, allocation is also carried out by custom. This continues to play a role in many countries in the developing world. However, the embedding of customary allocation practices within the modern state, understood as patronage or clientelism, helps to undermine the effectiveness of bureaucracy. 
First, the state needs to be able to maintain order and effectively enforce its rules. Ever since Weber (1978: 54), social scientists have understood that the essence of the state is the establishment and maintenance of order. Providing and enforcing a set of rules that govern relationships between those subject to the authority of the state is critical to development outcomes. Disorder wreaks havoc that undermines well-being directly, but also creates situations in which there is great uncertainty about property and contractual relationships, thus raising transaction costs and undermining production and investment (North 1991, Olson 1993). While this dimension does not fully capture everything that states do to create and support markets, it does capture one of the fundamental tasks it must accomplish for market success.

Second, the state also needs an effective apparatus to translate the preferences of its leaders into effective policy. Here we will examine bureaucratic capability, the ability of the offices of the state to accomplish its assigned tasks. The ability of political leadership to direct the bureaucracy and have it respond to commands in a timely and competent manner is essential to whether the elites commanding the state can translate their preferences into policy. Evans and Rauch (1999, also Rauch and Evans 2000) discuss this as a question of how closely the state apparatus conforms to the "Weberian" ideal type of bureaucracy. First of all, is the bureaucracy skilled, effectively organized, and does it have adequate resources? Second and no less important is whether it carries out directives from above. Has it been captured by private interests (economic actors, civil society groups, influential individuals) or do the directives of state leaders take precedence? Has the bureaucracy developed its own interests that interfere with the ability of those supposedly empowered to command? Ultimately, when the market provides inadequate incentives to maintain the levels of welfare desired by modern society, administrative means are 
a viable option for overcoming market failure. Countries without effective bureaucracies will be at a decided disadvantage in carrying out such welfare programs.

Maintenance of order and the establishment of effective bureaucracies that allow the state to affect the lives of citizens are two of the most basic fundamental components of what states do. We acknowledge that states often do more, but capturing these two dimensions is more than sufficient, given the propositions about state power we are testing here. ${ }^{3}$ While the exploration of these two aspects of the state is hardly new, they have yet to be linked to the provision of specific welfare outcomes. We will limit ourselves to the two areas identified above, law and order and bureaucratic effectiveness, and examine their impact on three widely acknowledged fundamental indicators of human welfare - infant mortality, per capita food supply, and education. Thus, our tests examine the impact of the order-enforcing and administrative apparatuses of the state on welfare outcomes.

On the most general level, we expect states that are unable to maintain order and states with less effective bureaucracies will produce less favorable welfare outcomes. However, given what we have argued above, the degree to which welfare depends on the market or administrative distribution will condition whether the state's ability to enforce order or the quality of its bureaucracy is more important to the outcome in question. In terms of the dependent variables in this paper, primary education, food supply and infant mortality, we expect that order and bureaucratic quality will have different effects on each. Given that healthcare in the developing world is largely dependent on networks of clinics and hospitals administered by the state, we expect

${ }^{3}$ One obvious dimension that we have omitted is the ability to raise revenue sufficient to support state action (See Arbetman and Kugler 1997; Bräutigam, Fjeldstad, and Moore 2008). 
that bureaucratic capacity will have strong effects on health care. In as much as food supply is more market dependent, we expect bureaucratic capacity to have less of an impact. Regarding the capacity of the state to maintain order, we would expect high levels of disorder to disrupt the provision of welfare goods and services delivered by both market and administrative means. However, at lower levels, we expect that disorder will have more disruptive effects on markets. Given our assumption that food supply is more dependent on markets than health care, we expect the former to be more prone to disruption by disorder. Finally, we expect education to be dependent on both. Of course, public schooling should be dependent on effective bureaucracy and where there is weak maintenance of law and order we expect the children of the poor in particular to be exposed to higher levels of criminality and violence which will disrupt their education.

Finally, there exists the possibility that state and regime may have interactive effects. It may be that certain kinds of regimes are better at providing for human needs when they have sufficient levels of state capacity but fall short in its absence. It is possible that previous findings that democracy provides superior human welfare outcomes could be a product of better utilization of state capacity by democratic regimes. Thus we will not only test for the independent effects of law and order and bureaucratic quality, but will test whether they have different impacts in different samples of countries based on whether they are democratic or not.

The ultimate verdict on whether the state, regime, or some combination of the two has an impact on welfare outcomes will be decided by our multivariate tests. In those tests, indicators of state capacity and regime-type will both appear on the right side of our regressions, and we will be able to isolate their potential effects. We now turn to a discussion of the design we will use to test our hypotheses.

\section{Research Design}


Sample

Studying both state capacity and human development outcomes using time series cross sectional methods is difficult. In both cases, it is hard to find data that captures each concept that is available over a broad cross-section of countries for a sustained period of time. Quite often even when a relatively broad cross-section of countries is available the sample overrepresents prosperous countries. In focusing on human development outcomes in the developing world, we have had to make difficult decisions about data and worked to maximize our observations temporally and geographically while maintaining reliability.

As our theoretical focus is the role of the state in developing countries, we exclude countries that were OECD members in 1984, the first year in our data set. Countries admitted to the OECD after this point in time remain in the dataset. To remove the most successful segment of developing countries from the dataset when they achieve success would potentially bias our sample.

Our unit of analysis is the country-year. In our tests the sample varies according to the extent to which data were available for the dependent variables. Our main models that test for determinants of infant mortality include 88 countries. The sample drops off in size for the food supply model to 85 countries, and to 81 for the primary education models. Our temporal domains vary slightly: for the infant mortality we have data from 1984 to 2012 . The food models are tested on data from 1984 to 2009 and primary education on data from 1984 to 2010. A detailed breakdown of the sample and descriptive statistics per indicator can be found on-line in the web appendix, Tables A1, A2, and A3.

Measuring Human Welfare 
No single measure captures human development in all its dimensions. Our research design acknowledges the heterogeneity of human welfare by using three measures: health, nutrition, and education - the infant mortality rate, per capita calorie supply, and years of primary schooling. By subjecting our hypotheses to tests using different measures we increase confidence in our larger claim. Our reason for using these three indicators are practical; they are among the few that are available for a large number of developing countries for a substantial period of time.

The Infant mortality rate (IMR) is the number of infant deaths (excluding stillbirths) in the first year of life out of every 1,000 births (World Bank 2013). Consistent with common practice in the study of infant health we log the variable (see e.g. Ross 2006, Kleinman 1986). Logging infant mortality rate makes comparisons across time and developing countries easier since the reduction of infant mortality rates is not linear. As infant mortality declines, more effort is needed to reduce it further; and it will never be below zero.

We measure food supply using kilocalories per capita on a daily basis as collected by the United Nations Food and Agriculture Organization (FAOSTAT 2013). It is presently available through 2009. Food supply is a good instrument for ascertaining how well the incompressible subsistence needs of a population is met (Bowman 2002; Reenock, Bernhard, and Sobek 2007). We also log food supply.

We measure basic education as average years of primary schooling by the age of twentyfive. The data come from Barro and Lee (2013), and are interpolated for the years between their five-year observations. The data are currently available through 2010 and we also log this dependent variable.

Measuring State Strength 
In line with our understanding of the state, we use disaggregated measures that tap into two of its central dimensions, the state's ability to maintain law and order and the quality of its bureaucracy, to link them to the specific welfare outcomes highlighted above. For both dimensions we used data from the International Country Risk Guide (ICRG) by the Political Risk Services Group (2013). The data are based on annual expert assessments and are available in country-year format starting in 1984 until 2012.

The ICRG data, like other reputational data, are subject to the critique that they are indirect measures that capture only the perceptions of those queried and not the true state of institutions. In the study of growth, one can argue that assessments will be positive when a country's growth performance, rather than institutional performance, is good (Rodrik 2004; Kurtz and Schrank 2008). In using them to gauge the impact of the state on infant mortality and food supply, we are relatively confident that we avoid this particular problem given that the experts and businessmen consulted by ICRG are not apt to base their assessments on human development outcomes.

In an ideal world, we would have preferred to use directly observable measures of state capacity. However, there is no data of this nature that is suitable for-cross national research with even moderately long time series for the developing world. Some have suggested homicide rates and the extent of the shadow economy might tap into rule of law, but the coverage of these indicators for a large number of states is not much longer than five years (Popov 2011, Schneider 2007). Other directly observable indicators of state capacity such as state expenditure or social spending are only consistently available for a small number of developed states as decade or longer time series. Our options were thus limited to the reputational assessments of state capacity. The World Bank Worldwide Governance Indicators (WGI) also offers disaggregated compo- 
nents of rule of law and government effectiveness. We ultimately opted to use the ICRG data for our main models because it starts in the1980s whereas the WGI codings only go back as far as 1996 (Kaufmann et al. 2010). We use the WGI indicators in robustness tests.

Aside from endogeneity and potential sample bias concerns, there is another important measurement problem that arises in work on the effect of political structures on development outcomes. Scholarship often aggregates a series of potential variables (e.g. government stability, law and order, socioeconomic conditions, accountability, bureaucratic quality, or corruption) that may or may not capture the outcome of interest into one indicator. With this kind of aggregation, governance measures undoubtedly increase the amount of statistical noise due to measurement error (Kurtz and Schrank 2008). We seek to minimize this problem via disaggregation. The ICRG law and order variable captures the ability of the state to enforce its rule. The variable ranges between 0 and 6 , where " 0 " represents the lowest level of law and order and " 6 " the highest. The average value of law and order is 3.36, with a standard deviation of 1.20. There are some countries that rated " 0 " on this variable for several years, e.g. the Democratic Republic of Congo, Somalia, and Sri Lanka. Some countries received the highest rating including Singapore, Morocco, and Namibia.

The ICRG measure of bureaucratic quality gauges the degree to which a bureaucracy is professional, transparent, and effective. Bureaucratic quality ranges between 0 and 4, where " 0 ” represents the lowest levels of bureaucratic quality and " 4 " the highest. The average value of bureaucratic quality is 1.81 , with a standard deviation of 0.94 . Several countries rate " 0 " on this scale, including Haiti, Sudan, Togo and Mali in various years. Both Hungary and South Africa attains scores of 4 in certain years.

\section{Control Variables}


Given the heterogeneity of our dependent variables, we include a range of control variables. Our most important control variable is level of democracy. Given the claims made for democracy in the literature, we will be able to gauge if it plays a role in driving our welfare outcomes of interest when we also control for the impact of state capacity. We control for the hypothesized positive impact of democracy on welfare by using the most recent version of the Polity 2 level of democracy variable. It is a 21 -point scale that runs from -10 to 10 , from least democratic to most (Marshall, Jaggers, and Gurr 2011).

To control for the impact of economic development and economic performance on welfare outcomes we include the natural log of income per capita (measured in constant 2000 US Dollars) and annual change in income per capita in all models (World Bank 2013). We control for the negative effects of civil war on human welfare using data from the PRIO Dataset on Armed Conflict (Gleditsch et al. 2002). A civil war is defined as a conflict that incurs at least 1,000 battle deaths. We would expect domestic conflict potentially to disrupt both public services and the operation of the market. Our conflict dummy, therefore, assumes the value of " 1 " if civil war is present.

A substantial literature on the "resource curse" talks about how an economy based on oil exports promotes prerogative state power and retards complex economic development despite the generation of wealth. To control for the fact that oil rich countries can generate wellendowed systems of transfer payments that enhance welfare while maintaining traditional patrimonial state structures we include a continuous oil variable that captures the per capita net value of oil exports measured in constant 2000 dollars (Ross 2013). In robustness tests (not reported) we substituted the per capita net value of gas exports measured in constant 2000 dollars. The re- 
sults did not change. Given the propensity of dominant ethnic elites to discriminate against other groups, we include a measure of ethnic fractionalization (Fearon 2003).

\section{Method}

Following Beck and Katz (1995) we use Prais-Winsten regressions with panel-corrected standard-errors (PCSEs) to analyze our time-series cross-sectional data. We investigate possible bias from serial correlation by employing the Durbin Watson test for first-order serial correlation. The significant test-statistic $(\mathrm{p}<0.01)$ indicates that we can reject the null of "no firstorder autocorrelation" and, consequently, chose to implement a Prais-Winsten transformation for every panel.

We also ran separate models on our sample partitioned by whether a country was ruled in a particular year by a democratic or an authoritarian regime. This allows us to look at whether state capacity has differential effects based on whether it is controlled by a democratic or authoritarian regime. ${ }^{4}$

To control for potentially exogenous time trends that may produce spurious findings, we include a year-count variable. ${ }^{5}$ All independent variables (except for GDP growth and ethnic fractionalization) are lagged one year since we expect their effects to be felt in the short term but

\footnotetext{
${ }^{4}$ We divided the sample using Polity2. We included any country year with score of six
} or higher in the democratic subsample, and below that threshold in the authoritarian (Marshall, Jaggers, and Gurr 2011).

${ }^{5}$ On average infant mortality has diminished over 30 percent between 1984 and 2012. Our independent variables also trend over time. 
not instantaneously. The three outcome variables are logged. Our models take the following forms:

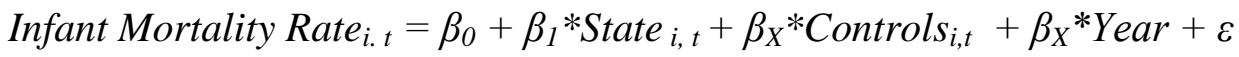

$$
\begin{aligned}
& \text { Food Supply }_{i, t}=\beta_{0}+\beta_{1} * \text { State }_{i, t}+\beta_{X} * \text { Controls }_{i, t}+\beta_{X} * \text { Year }+\varepsilon \\
& \text { Basic Education }_{i, t}=\beta_{0}+\beta_{1} * \text { State }_{i, t}+\beta_{X} * \text { Controls }_{i, t}+\beta_{X} * \text { Year }+\varepsilon
\end{aligned}
$$

We also conducted both individual and joint collinearity tests of our state capacity variables. The two measures correlate around 0.57 . Though this correlation is moderately strong, it suggests that they capture different dimensions. We performed tests to assure ourselves that putting both variables in the regression did not cause multicollinearity problems. ${ }^{6}$ Finally, we test our hypotheses using two-tailed tests.

\section{Results}

Main Models

Table 1 presents our main results for infant mortality. Model 1.1 is a base model that includes all controls but omits the state capacity variables. Like many regressions that test for the correlates of welfare outcomes, these results would seem to indicate that democracy has a significant negative effect on infant mortality. The first two models with state indicators (1.2 and 1.3) look at the law and order and bureaucratic quality variables separately with the full set of controls. Both are significant and signed negatively, consistent with the idea that state capacity lowers infant mortality. In these models, however, democracy is not significant. As expected higher

\footnotetext{
${ }^{6}$ We tested for multicollinearity in the models using the Variance Inflation Factor (VIF).
} The tests fell in the range that supported keeping both variables in the model. 
levels of GDP promote a lower rate of infant mortality, and ethnic fractionalization, the oil curse, and economic growth (unexpectedly) seem to contribute to higher levels of infant mortality.

In model 1.4 we include both law and order and bureaucratic quality in the same model and the results are substantively unchanged, though the magnitude of the coefficient on law and order and its statistical significance diminishes. Democracy remains insignificant. Finally, models 1.5 and 1.6 are split sample models that separately estimated the effects for democracies and authoritarian regimes. What is interesting here in comparison is that the effect of bureaucratic quality is similar across the two regime types, but that it differs for law and order. Here we see that the general result is more driven by variation across authoritarian regimes than democracies. These results in total are in line with our expectation that provision of health care in developing countries will be dependent on administrative means and thus more susceptible to bureaucratic quality.

\section{[Table 1]}

In interpreting the effects of our state variables, it is essential to remember that our dependent variables are logged. This means that the effects of unit changes in our state indicators, yield proportional changes in infant health. In particular, a coefficient of 0.02 for bureaucratic quality in model 1.4 suggests that a one unit increase in the four point bureaucratic quality scale results in a 2 percent reduction in infant mortality rates. The results for the six point law and order scale are more modest registering only 0.4 percent for a one-point increase.

In Table 2 we present the findings on food supply. Model 2.1 is a base model. In models 2.2 and 2.3 we include law and order and bureaucratic quality separately and find that only the former is significant and positive for food supply. As expected GNI per capita is significant and positive, while the oil curse and ethnic fractionalization exert negative and significant effects. 
Curiously, democracy has a negative coefficient on it, indicating that higher levels of democracy diminish food supply. In the base model it is insignificant but when we add the state variables it attains significance. This finding flies in the face of the recent literature on regime type and welfare outcomes. In model 2.4 these results hold when we include both bureaucratic quality and law and order.

Models 2.5 and 2.6 are split samples according to regime type. The most interesting result here is that the inclusive models on law and order seem to be driven by the authoritarian side of the full sample. Here only the law and order coefficient attains significance (model 2.6). The opposite signs on the coefficients for bureaucratic quality in models 2.5 and 2.6 help explain why this variable does not attain significance in the full sample models.

The impact of law and order on food supply brings relatively modest incremental improvements. A one-unit increase in the law and order index boils down to an increase of 0.7 percent in the food supply (model 2.4). In a country where the mean food supply is the UN subsistence minimum, 2400 kilocalories per capita per day, a one point improvement in the level of law and order would be an additional 17 kilocalories per person per day. In authoritarian countries (model 2.6) this increases to a 1.5 percent increase or 36 kilocalories per day per person. Of course, even small increases at low levels of food supply can make a difference to people on the margin, especially as those already well-off do not increase their caloric consumption as they get richer.

Table 3 presents the results for primary education. Models 3.2 and 3.3 present separate results for law and order and bureaucratic quality. Against our expectations, we only find a significant positive result for law and order. GNI per capita is significant and positive and emerges, not unexpectedly, as a universal predictor of human welfare outcomes. Again, the oil curse and 
ethnic fractionalization exert negative and significant effects, as does economic growth like it did for infant mortality. In this set of models, democracy and education are significantly and positively correlated in line with longstanding research on this relationship (Sokoloff and Engerman 2000). This is the one set of tests where there is a positive finding on democracy in the base model (3.1) and it persists when we introduce the state capacity variables. These results hold when we include both bureaucratic quality and law and order (model 3.4). In this model, a one point improvement in the level of law and order means a little less than aone percent increase in mean years of primary schooling. The mean country value in the sample is approximately four years of primary schooling which translates to an additional two-weeks of school per capita.

Models 3.5 and 3.6 present split samples according to regime type. Whereas the result for law and order is signed consistently across both sub-samples, the most interesting result here is the significant and negative result for bureaucracy in the model that isolates authoritarian regimes. This explains why bureaucratic quality fails to attain significance in the full sample models. This result is consistent with Przeworski et al.'s (2000, chapter 3) argument concerning the developmental differences between democracies and authoritarian regimes. The developmental model in the latter case stresses low return and investment in low-wage labor, and underlies their claims that authoritarian regimes produce inferior welfare outcomes. The impact of a one-point increase in the bureaucratic quality index means a barely perceptible 1.9 percent increase in mean years of primary schooling in a democracy and 3.2 percent decrease under authoritarian rule. The five percent difference between the two translates into a one-fifth of a year of schooling per child for a country at the mean value of 4 years of primary education per child.

We end this sub-section with some more global comments on all three sets of tests. First, these models confirm the idea that the omission of state capacity variables from tests of determi- 
nants of welfare outcomes leads to bias. One can see this in comparing the results of the base models to the models that include state capacity for infant mortality and food. In the former, the democracy variable becomes insignificant with the introduction of the state variables. In the latter case, an insignificant and negative coefficient becomes significant when the state variables are included. The impact of the introduction of the state variables on democracy is only inconsequential for education, where its effect remains positive and significant.

Second, the results of the split-sample models provide little evidence that the combination of democracy and higher state capacity promotes better human development outcomes. The one case we see that is for education, where the null result for the sample as a whole for bureaucratic capacity is driven by a positive effect in democracies and a negative effect in authoritarian regimes (models 3.4-3.6). Generally, we either see similar effects across regime types as with bureaucratic quality for IMR (models 1.5 and 1.6) or cases where the general results are driven more strongly by the effect of state capacity in the authoritarian sub-sample (law and order for education - models 3.4-3.6, law and order for food supply - models 2.4-2.6, law and order for IMR - models 1.4-1.6).

Robustness Checks

We now subject our findings to robustness tests. First, we re-estimate our Prais-Winsten models with additional controls. Second, we re-estimate the models using an alternative version of the main independent variables drawn from the World Bank Worldwide Governance Indicators (WGI). Specifically, we replace the ICRG law and order and bureaucratic quality variables with the WGI measures for rule of law and government effectiveness (Kaufmann, Kraay, and Mastruzzi 2014). Overall, these two checks support our findings but cause us to be cautious about some of them. 
Table 4 presents our original models adding controls for levels of tertiary education and fertility. $^{7}$ Both of these variables capture the degree of a society's commitment to human development outcomes. Tertiary education should capture the degree to which a society invests in human capital. It should also be strongly correlated with other human development outcomes as highly educated societies have been shown to be more concerned about quality of life issues (Inglehardt 1977, 1997). We include fertility to capture the change from societies that have made the demographic shift from large to small families. Such developments entail a fundamental change in the role of women in society and the strategies that families pursue to see to their longterm well-being. This demographic shift causes greater investment by societies and families in individual children and women, and thus should be associated with greater commitment to welfare outcomes (Przeworski, et al. 2000, chapter 5).

[Table 4]

The results for these regressions with additional, potentially confounding, variables are supportive of our original findings on the relationship between bureaucratic capacity and IMR and between law and order and food supply. The results for law and order on education and IMR are not reproduced. Democracy continues to be significant and positive for education. [Table 5]

\footnotetext{
${ }^{7}$ We omit tertiary education from the primary education model due to their high degree of correlation. In the infant mortality and food models we include both tertiary education and fertility. The education data come from Barro and Lee (2013) and are interpolated for the years between their five-year observations. The data for our fertility come from the World Bank Development Indicators 2013. To improve coverage we interpolated the data.
} 
In Table 5 we estimate our original models using alternative versions of our main independent variables for state capacity from WGI. The results for infant mortality are robust with both government effectiveness and rule of law having a significant effect in reducing fatalities (model 5.1). This reproduces our original findings for bureaucratic effectiveness and law and order in Table 1. Using this alternative specification, we also see a positive impact for rule of law on food supply (model 5.2), replicating the positive effects we found for law and order in Table 2. The results for education (model 5.3) like the models in Table 3 find that democracy has a positive effect on education. The results for rule of law are not robust for primary education, supporting our null finding for law and order (model 4.3) which raised doubts concerning

the findings in Table 3. Model 5.3 also reports unexpectedly that bureaucratic quality exerts a significant negative effect on education. This is not a finding that we have seen earlier, except in the split sample model for authoritarian states. It is possible that the smaller sample size in this regression may have something to do with this unexpected finding. Finally, our results for democracy in these models follow the patterns in the main models.

\section{Discussion and Conclusions}

The evidence that we present in our models above provides support for the hypotheses generated by our disaggregated Weberian approach to the state. We turn up two strong findings. With regard to infant mortality, we have confidence that bureaucratic quality exerts a reductive effect. The results with regard to law and order are inconsistent between our main models and one of our robustness tests, so we are less convinced that law and order has the reductive effect found in the main model. With regard to food supply, we achieve our strongest result with law and order. It achieves significance in the main models and the robustness checks. The results on 
primary education are the weakest for the state capacity variables. While in the main model only law and order is positive and significant, this is not reproduced in the robustness checks.

Overall, these findings support our contention that the omission of the role of the state structures in quantitative literature on welfare outcomes is a significant oversight. The coefficients and significance of the democracy variable are highly susceptible to change when we add state capacity variables to the regressions. The tests also demonstrate the utility of our theoretical framework linking welfare outcomes to specific facets of state capacity based on whether they are more dependent on the market safeguarding or administrative components of state action.

With regard to democracy, we only have one consistent finding, that it is important in the provision of primary education. With regard to food supply and infant mortality, the effects of select aspects of state capacity seem to be more important. While our findings support Ross' (2006) contention that democracy is an inconsistent indicator of human development outcomes, our logic is somewhat different. Whereas Ross contends that the positive results for democracy are a product of sample bias, our work suggests that it is also a product of omitted variable bias.

We count ourselves among those who see strong advantages to democracy as a political system, but these findings should promote skepticism that democracy in itself automatically promotes the welfare of its citizens in the absence of an effective state. The finding that there is little difference between democracy and authoritarianism in promoting welfare outcomes, provides no justification for earlier arguments that authoritarianism is a necessary condition for material progress or the more recent iconoclastic policy prescriptions for "benevolent" dictatorship as the best path out of poverty (Moyo 2009: 42-5). Even our split sample models which show that authoritarian regimes with superior state capacity help to produce better human development outcomes cannot be interpreted in this fashion. 
Our findings also lead us to call for a broader conceptualization of institutions, to think about both regime-type and the role of the state as relevant to accounting for developmental outcomes. Our work shows that components of state action have different effects on different development outcomes. Where possible, tests of the effect of regime on welfare outcomes should also include variables that capture the effects of state capacity. Second, our split sample models show that, sometimes, state capacity and regime interact in important ways. On several occasions we show that the results we generate for the samples as whole are driven by a stronger association with either the democratic or authoritarian subsamples of the whole. This is most marked in our analysis of primary education where, under authoritarian conditions, state capacity has the effect of lowering education outcomes.

The limitations of our findings are that they do not capture the full impact of the state. Rather, our findings are confined to the public order and bureaucratic dimensions of the state. Clearly there is more research to be done here, especially with regard to the revenue dimension. Last but not least, our findings have obvious policy implications. They support the stances taken by public intellectuals such as Diamond (2007) and Fukuyama (2004) on the underappreciation of the state as a factor in promoting development and democracy. As Stiglitz et al. (2006) have argued, it is not only the freeing of markets that produces positive development outcomes; other institutions matter as well. Whether a country is a democracy or a dictatorship, effective legal and bureaucratic institutions will help to improve the population's quality of material life. As citizen life satisfaction promotes stable democracy, their concern that democratization is more likely to fail in the absence of adequate state capacity is well-founded. 


\section{Works Cited}

Acemoglu, Daron and James Robinson. 2006. Economic Origins of Dictatorship and Democracy. Cambridge, Cambridge University Press.

Amsden, Alice H. 2001. The Rise of the Rest: Challenges to the West from Late-Industrializing Economies. Oxford University Press, Oxford.

Arbetman, Marina and Jacek Kugler. 1997. Political Capacity and Economic Behavior. Boulder, Westview Press.

Barro, Robert J. 1998. Determinants of Economic Growth: A Cross-Country Empirical Study. Cambridge, MIT Press.

Barro, Robert J. and Jong Wha Lee. 2013. "A New Data Set of Educational Attainment in the World, 1950-2010,” Journal of Development Economics 104: 184-198.

Baum, Matthew A. and David A. Lake. 2003. "The Political Economy of Growth: Democracy and Human Capital." American Journal of Political Science 47:333-347.

Beck, Nathaniel and Jonathan N. Katz, 1995. "What to Do (and Not to Do) with Time-Series Cross-Section Data in Comparative Politics," American Political Science Review 89:634-47.

Besley, Tim and Masayuki Kudamatsu. 2006. "Health and Democracy," American Economic Review $96: 313-318$.

Boix, Carles. 2003. Democracy and Redistribution. Cambridge: Cambridge University Press.

Bowman, Kirk S. 2002. "Will Vote for Food? Regime Type and Equity in the Developing World." Politics and Policy 30:1-25.

Bräutigam, Deborah, Odd-Helge Fjeldstad, and Mick Moore, eds. 2008. Taxation and StateBuilding in Developing Countries. Cambridge, Cambridge University Press.

Brown, David S., and Wendy Hunter. 1999. "Democracy and Social Spending in Latin America, 1980-1992.” American Political Science Review 93:779-790.

---------. 2000. "Democracy and Human Capital Formation-Education Spending in Latin America, 1980 to 1997," Comparative Political Studies 37: 842-864.

Chong, Alberto and César Calderón. 2000. "Institutional Quality and Poverty Measures in a Cross-section of Countries," Economics of Governance 1: 123-135.

Chirot, Daniel. 1977. Social Change in the Twentieth Century. New York, Harcourt Brace Jovanovich. 
Diamond, Larry. 2007. “A Quarter-century of Promoting Democracy.” Journal of Democracy 18:118-20.

Easton, David. 1953. The Political System: An Inquiry into the State of Political Science. New York, Alfred A. Knopf, 1953.

Evans, Peter. 1995. Embedded Autonomy: States and Industrial Transformation. Princeton University Press, Princeton.

Evans, Peter and James Rauch. 1999. "Bureaucracy and Growth: a Cross-national Analysis of the Effects of 'Weberian' State Structures on Economic Growth." American Sociological Review 64: 748-765.

FAOSTAT. 2013. Food Balance Sheets. http://faostat3.fao.org/faostatgateway/go/to/download/C/CC/E (Accessed 9/30/2013).

Fearon, James and David Laitin. 2003. "Ethnicity, Insurgency, and Civil War." American Political Science Review 97: 75-90.

Fearon, James. 2003. "Ethnic and Cultural Diversity by Country." Journal of Economic Growth 8: $195-222$.

Fukuyama, Francis. 2004. State-Building: Governance and World Order in the 21st Century. Ithaca, Cornell University Press.

Gerring, John, Philip Bond, William T. Barndt, and Carola Moreno. 2005. "Democracy and Economic Growth: A Historical Perspective." World Politics 57: 323-367.

Gerschenkron, Alexander. 1962. Economic Backwardness in Historical Perspective. Harvard University Press, Cambridge.

Gleditsch, Nils Petter; Peter Wallensteen, Mikael Eriksson, Margareta Sollenberg \& Håvard Strand. 2002. "Armed Conflict 1946-2001: A New Dataset," Journal of Peace Research 39: 615-637.

Haggard, Stephan. 1990. Pathways from the Periphery. Cornell University Press, Ithaca.

Haggard, Stephan and Robert R. Kaufman. 2008. Development, Democracy, and Welfare States: Latin America, East Asia, and Eastern Europe. Princeton, Princeton University Press.

Hirschman, Albert O. 1968. The Political Economy of Import Substituting Industrialization in Latin America. Quarterly Journal of Economics 82: 1-32. 
Huber, Evelyne, Thomas Mustillo and John D. Stephens. 2008. "Politics and Social Spending in Latin America," The Journal of Politics 70 :420-436.

Huntington, Samuel. 1968. Political Order in Changing Societies. New Haven, Yale University Press.

Inglehardt, Ronald. 1977. The Silent Revolution. Princeton, Princeton University Press.

Inglehardt, Ronald. 1997. Modernization and Postmodernization. Princeton, Princeton University Press.

Khan, Mushtaq. 2006, "Governance and Development," Workshop on Governance and Development' organized by the World Bank and DFID, 11-12 November, Dhaka, Bangladesh .

Karakoc, Ekrem. 2010. The Democracy and Equality Paradox: How Democracy has Increased Income Disparities in Postcommunist and Southern Europe. Ph.D. Dissertation, Department of Political Science, The Pennsylvania State University, May 2010.

Kaufmann, Daniel, Aart Kraay and Massimo Mastruzzi. 2010. The Worldwide Governance Indicators: Methodology and Analytical Issues.

http://info.worldbank.org/governance/wgi/pdf/WGI.pdf (accessed February 29, 2012).

Kaufmann Daniel, Aart Kraay, and Massimo Mastruzzi. 2014. Worldwide Governance Indicators. http://info.worldbank.org/governance/wgi/index.aspx\#home (accessed June 15, 2014).

Kaufmann, Daniel, Aart Kraay, and Pablo Zoido-Lobaton. 1999. "Governance Matters.” Poverty Reduction Working Paper 2195, World Bank, Washington D.C.

Kaufman, Robert A. and Alex Segura-Ubiergo. 2001. "Globalization, Domestic Politics, and Social Spending in Latin America: A Time-Series Cross-Section Analysis, 1973-97." World Politics 53: 553-587.

Keefer, Philip. 2007. "Clientelism, Credibility, and the Policy Choices of Young Democracies," American Journal of Political Science 51 : 804-821.

Kleinman, Joel C. 1986. "Further Comments on 'State Trends in Infant Mortality."' American Journal of Public Health 76 :1361-1362.

Kohli, Atul. 2004. State-Directed Development: Political Power and Industrialization in the Global Periphery. Cambridge, Cambridge University Press.

Kurtz, Marcus and Andrew Schrank. 2008. "Growth and Governance: Models, Measures, and Mechanisms." Journal of Politics 69:538-554. 
Lake, David A., and Matthew A. Baum. 2001. "The Invisible Hand of Democracy: Political Control and the Provision of Public Services." Comparative Political Studies 34:587-621.

Marshall, Monte G., Keith Jaggers, and Ted R. Gurr, 2011. "Polity IV Project: Political Regime Characteristics and Transitions, 1800-2011," http://www.systemicpeace.org/polity/polity4.htm, (accessed January 2, 2014).

Mauro, Paolo. 1995. “Corruption and Growth.” Quarterly Journal of Economics 110: 681-712.

Meltzer, Allan H. and Scott F. Richard. 1981. "A Rational Theory of the Size of Government," Journal of Political Economy 89 : 914-927.

Moyo, Dambiso. 2009. Dead Aid: Why Aid Is Not Working and How There Is a Better Way for Africa. New York, Farrar Straus and Giroux.

North, Douglas 1991. Institutions, Institutional Change, and Economic Performance. Cambridge, Cambridge University Press.

O’Donnell, Guillermo. 1973. Modernization and Bureaucratic Authoritarianism. Berkeley, Institute of International Studies.

Olson, Mancur. 1993. "Dictatorship, Democracy, and Development. The American Political Science Review 87:567-576.

Political Risk Services Group. 2012. "International Country Risk Guide (ICRG)," http://www.prsgroup.com/prsgroup_shoppingcart/pc-32-4-researcher-dataset-icrg-t3b.aspx, (accessed 10/05/13).

Popov, Vladimir. 2011. "Developing New Measurements of State Institutional Capacity," PONARS Eurasia Policy Memo 158 http://pages.nes.ru/vpopov/documents/Institutional capacity measurement-PONARS-May 2011.pdf (accessed February 29, 2012).

Przeworski, Adam, Michael Alvarez, Jose Antonio Cheibub, and Fernando Limongi. 2000..Democracy and Development. Cambridge: Cambridge University Press.

Rauch, James. E. and Peter B. Evans. 2000. "Bureaucratic Structure and Bureaucratic Performance in Less Developed Countries," Journal of Public Economics 75 :49-71.

Reenock, Christopher, Michael Bernhard and David Sobek. 2007. "Regressive Socioeconomic Distribution and Democratic Survival." International Studies Quarterly 51: 677-699.

Rodrik, Dani. 1997. “What Drives Public Employment?” NBER Working Paper 6141.

---. 2004. “Getting Institutions Right.”CESifo DICE Report 2: 10-15. 
Ross, Michael, 2006. “Is Democracy Good for the Poor?” American Journal of Political Science 50: $860-874$.

Ross, Michael, 2013, "Oil and Gas Data, 1932-2011", http://hdl.handle.net/1902.1/20369

Rudra, Nita 2002. "Globalization and the Decline of the Welfare State in Less Developed Countries." International Organization 56: 411-445.

Rudra, Nita and Stephan Haggard. 2005. "Globalization, Democracy, and Effective Welfare Spending in the Developing World.” Comparative Political Studies 39:943-968.

Schneider, Friedrich. 2007. "Shadow Economies and Corruption All Over the World: What Do We Really Know?" Economics Discussion Papers, No 2007-9, http://www.economicsejournal.org/economics/discussionpapers/2007-9 (accessed February 29, 2012).

de Schweinitz, Karl. 1964. Industrialization and Democracy. New York, Free Press.

Stasavage, David. 2005. "Democracy and Education Spending in Africa," American Journal of Political Science 49 :343-358.

Sokoloff, Kenneth L. and Stanley L. Engerman. 2000. "Institutions, Factor Endowments, and Paths of Development in the New World," Journal of Economic Perspectives 14: 217-232.

Joseph Stiglitz, José Antonio Ocampo, Shari Spiegel, Ricardo Ffrench-Davis, and Deepak Nayyar. 2006. Stability with Growth: Macroeconomics, Liberalization and Development. Oxford, Oxford University Press.

Wade, Robert. 1990. Governing the Market: Economic Theory and the Role of Government in East Asian Industrialization. Princeton, Princeton University Press.

Weber, Max. 1946. "Politics as a Vocation." In From Max Weber. Hans Gerth and C. Wright Mills, eds. Oxford, Oxford University Press.

---. 1978. Economy and Society. Berkeley, University of California Press.

---. 1981. General Economic History. New Brunswick, Transaction Press.

Wigley, Simon and Arzu Akkoyunlu-Wigley. 2011a. "Do Electoral Institutions Have an Impact on Population Health?” Public Choice 148: 595-610.

Wigley, Simon and Arzu Akkoyunlu-Wigley. 2011b. "The Impact of Regime-Type on Health: Does Redistribution Explain Everything?” World Politics 63: 647-677.

World Bank. 2013. World Development Indicators 2013. http:// http://data.worldbank.org/datacatalog/world-development-indicators/wdi-2013 (accessed September 23, 2013). 
Table 1. Prais-Winsten Estimations of Infant Mortality (panel corrected standard errors in parentheses)

\begin{tabular}{|c|c|c|c|c|c|c|}
\hline & $\begin{array}{c}\text { Model } 1.1 \\
\text { All }\end{array}$ & $\begin{array}{c}\text { Model } 1.2 \\
\text { All }\end{array}$ & $\begin{array}{c}\text { Model } 1.3 \\
\text { All }\end{array}$ & $\begin{array}{c}\text { Model } 1.4 \\
\text { All }\end{array}$ & $\begin{array}{c}\text { Model } 1.5 \\
\text { Democratic }\end{array}$ & $\begin{array}{l}\text { Model } 1.6 \\
\text { Authoritarian }\end{array}$ \\
\hline Law and Order & & $\begin{array}{l}-0.007 * * * \\
(0.002)\end{array}$ & & $\begin{array}{l}-0.004 * \\
(0.002)\end{array}$ & $\begin{array}{l}-0.003 \\
(0.004)\end{array}$ & $\begin{array}{l}-0.015 * * \\
(0.007)\end{array}$ \\
\hline Bureaucratic Quality & & & $\begin{array}{l}-0.022 * * * \\
(0.005)\end{array}$ & $\begin{array}{l}-0.020 * * * \\
(0.005)\end{array}$ & $\begin{array}{l}-0.025^{* * *} \\
(0.009)\end{array}$ & $\begin{array}{l}-0.016 * * \\
(0.008)\end{array}$ \\
\hline Democracy & $\begin{array}{l}-0.001 * \\
(0.000)\end{array}$ & $\begin{array}{c}0.000 \\
(0.001)\end{array}$ & $\begin{array}{c}0.000 \\
(0.001)\end{array}$ & $\begin{array}{l}0.000 \\
(0.001)\end{array}$ & & \\
\hline GNI per capita & $\begin{array}{l}-0.440 * * * \\
(0.035)\end{array}$ & $\begin{array}{l}-0.431 * * * \\
(0.031)\end{array}$ & $\begin{array}{l}-0.426 * * * \\
(0.029)\end{array}$ & $\begin{array}{l}-0.420 * * * \\
(0.033)\end{array}$ & $\begin{array}{l}-0.487 * * * \\
(0.041)\end{array}$ & $\begin{array}{l}-0.436^{* * * *} \\
(0.024)\end{array}$ \\
\hline GNI growth & $\begin{array}{l}0.002 * * * \\
(0.000)\end{array}$ & $\begin{array}{l}0.002 * * * \\
(0.000)\end{array}$ & $\begin{array}{l}0.002 * * * \\
(0.000)\end{array}$ & $\begin{array}{l}0.002 * * * \\
(0.000)\end{array}$ & $\begin{array}{l}0.002 * * * \\
(0.000)\end{array}$ & $\begin{array}{l}0.002 * * * \\
(0.001)\end{array}$ \\
\hline Domestic Conflict & $\begin{array}{l}\text { '0.008*** } \\
(0.003)\end{array}$ & $\begin{array}{c}0.005 * \\
(0.003)\end{array}$ & $\begin{array}{c}0.005 \\
(0.003)\end{array}$ & $\begin{array}{c}0.004 \\
(0.003)\end{array}$ & $\begin{array}{c}0.005 \\
(0.004)\end{array}$ & $\begin{array}{c}0.002 \\
(0.006)\end{array}$ \\
\hline Oil & $\begin{array}{l}0.478^{* *} \\
(0.212)\end{array}$ & $\begin{array}{l}0.411 * \\
(0.220)\end{array}$ & $\begin{array}{l}0.464 * * * \\
(0.174)\end{array}$ & $\begin{array}{l}0.406 * * \\
(0.188)\end{array}$ & $\begin{array}{l}0.979 \\
(0.795)\end{array}$ & $\begin{array}{l}0.388 * * \\
(0.185)\end{array}$ \\
\hline Ethnic Fractionalization & $\begin{array}{l}0.700 * * * \\
(0.059)\end{array}$ & $\begin{array}{l}0.681 * * * \\
(0.051)\end{array}$ & $\begin{array}{l}0.872 * * * \\
(0.056)\end{array}$ & $\begin{array}{l}0.786^{* * * *} \\
(0.055)\end{array}$ & $\begin{array}{l}0.659^{* * * *} \\
(0.054)\end{array}$ & $\begin{array}{l}0.616^{* * * *} \\
(0.062)\end{array}$ \\
\hline $\mathrm{N}$ & 2165 & 1780 & 1780 & 1780 & 894 & 887 \\
\hline
\end{tabular}

Two-tailed tests. $* \mathrm{p}<0.10, * * \mathrm{p}<0.05, * * * \mathrm{p}<0.01$

Time trend variable (calendar year) included, but not reported. 
Table 2. Prais-Winsten Estimations of Food Supply (panel corrected standard errors in parentheses)

\begin{tabular}{|c|c|c|c|c|c|c|}
\hline & $\begin{array}{c}\text { Model } 2.1 \\
\text { All }\end{array}$ & $\begin{array}{c}\text { Model } 2.2 \\
\text { All }\end{array}$ & $\begin{array}{c}\text { Model } 2.3 \\
\text { All }\end{array}$ & $\begin{array}{c}\text { Model } 2.4 \\
\text { All }\end{array}$ & $\begin{array}{c}\text { Model } 2.5 \\
\text { Democratic }\end{array}$ & $\begin{array}{l}\text { Model } 2.6 \\
\text { Authoritarian }\end{array}$ \\
\hline Law and Order & & $\begin{array}{l}0.006 * * * \\
(0.002)\end{array}$ & & $\begin{array}{l}0.007 * * * \\
(0.002)\end{array}$ & $\begin{array}{c}0.003 \\
(0.002)\end{array}$ & $\begin{array}{l}0.015^{* * *} \\
(0.003)\end{array}$ \\
\hline Bureaucratic Quality & & & $\begin{array}{l}-0.002 \\
(0.003)\end{array}$ & $\begin{array}{l}-0.004 \\
(0.003)\end{array}$ & $\begin{array}{c}0.004 \\
(0.004)\end{array}$ & $\begin{array}{l}-0.003 \\
(0.003)\end{array}$ \\
\hline Democracy & $\begin{array}{l}-0.000 \\
(0.000)\end{array}$ & $\begin{array}{l}-0.002^{* * * *} \\
(0.001)\end{array}$ & $\begin{array}{l}-0.001 * * * \\
(0.001)\end{array}$ & $\begin{array}{l}-0.002^{* * *} \\
(0.001)\end{array}$ & & \\
\hline GNI per capita & $\begin{array}{l}0.096^{* * * *} \\
(0.003)\end{array}$ & $\begin{array}{l}0.076^{* * * *} \\
(0.004)\end{array}$ & $\begin{array}{l}0.081 * * * \\
(0.004)\end{array}$ & $\begin{array}{l}0.078 * * * \\
(0.004)\end{array}$ & $\begin{array}{l}0.096^{* * *} \\
(0.005)\end{array}$ & $\begin{array}{l}0.102^{* * *} \\
(0.006)\end{array}$ \\
\hline GNI growth & $\begin{array}{l}-0.000 * * * \\
(0.000)\end{array}$ & $\begin{array}{c}0,000 \\
(0.000)\end{array}$ & $\begin{array}{l}-0.000^{*} \\
(0.000)\end{array}$ & $\begin{array}{c}0,000 \\
(0.000)\end{array}$ & $\begin{array}{c}0,000 \\
(0.000)\end{array}$ & $\begin{array}{c}0,000 \\
(0.000)\end{array}$ \\
\hline Domestic Conflict & $\begin{array}{l}-0.004 \\
(0.003)\end{array}$ & $\begin{array}{l}-0.002 \\
(0.003)\end{array}$ & $\begin{array}{l}-0.002 \\
(0.003)\end{array}$ & $\begin{array}{l}-0.002 \\
(0.003)\end{array}$ & $\begin{array}{c}0.002 \\
(0.004)\end{array}$ & $\begin{array}{l}-0.001 \\
(0.004)\end{array}$ \\
\hline Oil & $\begin{array}{l}-0.267 * * * \\
(0.003)\end{array}$ & $\begin{array}{l}-0.098^{*} \\
(0.052)\end{array}$ & $\begin{array}{l}-0.158 * * * \\
(0.057)\end{array}$ & $\begin{array}{l}-0.096^{*} \\
(0.053)\end{array}$ & $\begin{array}{l}-1.431 * * * \\
(0.172)\end{array}$ & $\begin{array}{l}-0.287 * * * \\
(0.059)\end{array}$ \\
\hline Ethnic Fractionalization & $\begin{array}{l}-0.074 * * * \\
(0.010)\end{array}$ & $\begin{array}{l}-0.166^{* * * *} \\
(0.015)\end{array}$ & $\begin{array}{l}-0.153 * * * \\
(0.012)\end{array}$ & $\begin{array}{l}-0.165^{* * *} \\
(0.015)\end{array}$ & $\begin{array}{l}-0.062 * * * \\
(0.019)\end{array}$ & $\begin{array}{l}-0.188^{* * * *} \\
(0.012)\end{array}$ \\
\hline $\mathrm{N}$ & 1911 & 1568 & 1568 & 1568 & 817 & 753 \\
\hline
\end{tabular}

Two-tailed tests. $* \mathrm{p}<0.10, * * \mathrm{p}<0.05, * * * \mathrm{p}<0.01$

Time trend variable (calendar year) included, but not reported. 
Table 3. Prais-Winsten Estimations of Education (panel corrected standard errors in parentheses)

\begin{tabular}{|c|c|c|c|c|c|c|}
\hline & $\begin{array}{c}\text { Model } 3.1 \\
\text { All }\end{array}$ & $\begin{array}{c}\text { Model } 3.2 \\
\text { All }\end{array}$ & $\begin{array}{c}\text { Model } 3.3 \\
\quad \text { All }\end{array}$ & $\begin{array}{c}\text { Model } 3.4 \\
\text { All }\end{array}$ & $\begin{array}{c}\text { Model } 3.5 \\
\text { Democratic }\end{array}$ & $\begin{array}{c}\text { Model } 3.6 \\
\text { Authoritarian }\end{array}$ \\
\hline Law and Order & & $\begin{array}{l}0.009 * * * \\
(0.003)\end{array}$ & & $\begin{array}{l}0.009 * * * \\
(0.003)\end{array}$ & $\begin{array}{c}0.002 \\
(0.003)\end{array}$ & $\begin{array}{l}0.025^{* * *} \\
(0.007)\end{array}$ \\
\hline Bureaucratic Quality & & & $\begin{array}{c}0.006 \\
(0.005)\end{array}$ & $\begin{array}{c}0.004 \\
(0.005)\end{array}$ & $\begin{array}{l}0.019 * * * \\
(0.006)\end{array}$ & $\begin{array}{l}-0.032 * * * \\
(0.009)\end{array}$ \\
\hline Democracy & $\begin{array}{l}0.003 * * * \\
(0.001)\end{array}$ & $\begin{array}{l}0.003 * * * \\
(0.001)\end{array}$ & $\begin{array}{l}0.003 * * * \\
(0.001)\end{array}$ & $\begin{array}{l}0.003^{* * * *} \\
(0.001)\end{array}$ & & \\
\hline GNI per capita & $\begin{array}{l}0.214 * * * \\
(0.021)\end{array}$ & $\begin{array}{l}0.202 * * * \\
(0.024)\end{array}$ & $\begin{array}{l}0.203 * * * \\
(0.025)\end{array}$ & $\begin{array}{l}0.203 * * * \\
(0.024)\end{array}$ & $\begin{array}{l}0.286^{* * *} \\
(0.026)\end{array}$ & $\begin{array}{l}0.193 * * * \\
(0.025)\end{array}$ \\
\hline GNI growth & $\begin{array}{l}-0.001 * * * \\
(0.000)\end{array}$ & $\begin{array}{l}-0.001 * * * \\
(0.000)\end{array}$ & $\begin{array}{l}-0.001 * * * \\
(0.000)\end{array}$ & $\begin{array}{l}-0.001 * * * \\
(0.000)\end{array}$ & $\begin{array}{l}-0.001 * * * \\
(0.000)\end{array}$ & $\begin{array}{l}-0.001 * * \\
(0.000)\end{array}$ \\
\hline Domestic Conflict & $\begin{array}{l}-0.004 \\
(0.003)\end{array}$ & $\begin{array}{l}-0.003 \\
(0.003)\end{array}$ & $\begin{array}{l}-0.004 \\
(0.003)\end{array}$ & $\begin{array}{l}-0.003 \\
(0.003)\end{array}$ & $\begin{array}{l}0.001 \\
(0.005)\end{array}$ & $\begin{array}{l}-0.004 \\
(0.007)\end{array}$ \\
\hline Oil & $\begin{array}{l}-0.754 * * * \\
(0.194)\end{array}$ & $\begin{array}{l}-0.645^{* * *} \\
(0.181)\end{array}$ & $\begin{array}{l}-0.659 * * * \\
(0.196)\end{array}$ & $\begin{array}{l}-0.663 * * * \\
(0.187)\end{array}$ & $\begin{array}{l}-0.45 \\
(0.388)\end{array}$ & $\begin{array}{l}-0.428 * * \\
(0.181)\end{array}$ \\
\hline Ethnic Fractionalization & $\begin{array}{l}-0.418^{* * * *} \\
(0.080)\end{array}$ & $\begin{array}{l}-0.514 * * * \\
(0.089)\end{array}$ & $\begin{array}{l}-0.511^{* * * *} \\
(0.089)\end{array}$ & $\begin{array}{l}-0.498 * * * \\
(0.087)\end{array}$ & $\begin{array}{l}-0.863^{* * *} \\
(0.099)\end{array}$ & $\begin{array}{l}-0.027 \\
(0.077)\end{array}$ \\
\hline $\mathrm{N}$ & 1877 & 1609 & 1609 & 1609 & 832 & 777 \\
\hline
\end{tabular}

Two-tailed tests. $* \mathrm{p}<0.10, * * \mathrm{p}<0.05, * * * \mathrm{p}<0.01$

Time trend variable (calendar year) included, but not reported. 
Table 4. Prais-Winsten Models with Added Controls (panel corrected standard errors in parentheses)

\begin{tabular}{|c|c|c|c|}
\hline & $\begin{array}{c}\text { Model } 4.1 \\
\text { Infant } \\
\text { Mortality } \\
\end{array}$ & $\begin{array}{c}\text { Model } 4.2 \\
\text { Food } \\
\text { Supply }\end{array}$ & $\begin{array}{c}\text { Model } 4.3 \\
\text { Primary } \\
\text { Education }\end{array}$ \\
\hline Law and Order & $\begin{array}{l}-0.001 \\
(0.002)\end{array}$ & $\begin{array}{l}0.006^{* * *} \\
(0.002)\end{array}$ & $\begin{array}{c}0.000 \\
(0.003)\end{array}$ \\
\hline Bureaucratic Quality & $\begin{array}{l}-0.022 * * * \\
(0.004)\end{array}$ & $\begin{array}{l}-0.002 \\
(0.003)\end{array}$ & $\begin{array}{c}0.003 \\
(0.004)\end{array}$ \\
\hline Democracy & $\begin{array}{c}0.000 \\
(0.001)\end{array}$ & $\begin{array}{l}-0.001 \\
(0.001)\end{array}$ & $\begin{array}{l}0.001 * * \\
(0.001)\end{array}$ \\
\hline GNI per capita & $\begin{array}{l}-0.297 * * * \\
(0.034)\end{array}$ & $\begin{array}{l}0.054 * * * \\
(0.005)\end{array}$ & $\begin{array}{l}0.074 * * * \\
(0.012)\end{array}$ \\
\hline GNI growth & $\begin{array}{l}0.001 * * * \\
(0.000)\end{array}$ & $\begin{array}{c}0.000 \\
(0.000)\end{array}$ & $\begin{array}{l}-0.000 * * \\
(0.000)\end{array}$ \\
\hline Domestic Conflict & $\begin{array}{c}0.004 \\
(0.003)\end{array}$ & $\begin{array}{c}0.001 \\
(0.003)\end{array}$ & $\begin{array}{l}-0.001 \\
(0.002)\end{array}$ \\
\hline Oil & $\begin{array}{c}0.309 * \\
(0.182)\end{array}$ & $\begin{array}{c}0.001 \\
(0.047)\end{array}$ & $\begin{array}{l}-0.088 \\
(0.084)\end{array}$ \\
\hline Ethnic Fractionalization & $\begin{array}{l}0.547 * * * \\
(0.117)\end{array}$ & $\begin{array}{l}-0.129 * * * \\
(0.025)\end{array}$ & $\begin{array}{l}-0.085 * \\
(0.052)\end{array}$ \\
\hline Female Fertility & $\begin{array}{l}0.085^{* * * *} \\
(0.016)\end{array}$ & $\begin{array}{l}-0.004 \\
(0.005)\end{array}$ & $\begin{array}{l}-0.195 * * * \\
(0.013)\end{array}$ \\
\hline Tertiary Education & $\begin{array}{l}-0.203 * * * \\
(0.034)\end{array}$ & $\begin{array}{l}0.053^{* * *} * \\
(0.007)\end{array}$ & \\
\hline $\mathrm{N}$ & 1576 & 1409 & 1541 \\
\hline
\end{tabular}

Two-tailed tests. $* \mathrm{p}<0.10, * * \mathrm{p}<0.05, * * * \mathrm{p}<0.01$

Time trend variable (calendar year) included, but not reported. 
Table 5. Prais-Winsten Models Using World Bank Governance Indicators (panel corrected standard errors in parentheses)

\begin{tabular}{llll}
\hline & $\begin{array}{c}\text { Model 5.1 } \\
\text { Infant } \\
\text { Mortality }\end{array}$ & $\begin{array}{c}\text { Model 5.2 } \\
\text { Food }\end{array}$ & $\begin{array}{l}\text { Model 5.3 } \\
\text { Primary }\end{array}$ \\
\hline Rule of Law & $-0.110^{* * *}$ & $0.018 *$ & 0.016 \\
& $(0.017)$ & $(0.010)$ & $(0.018)$ \\
Government Effectiveness & $-0.049 * * *$ & 0.001 & $-0.058^{* *}$ \\
& $(0.015)$ & $(0.008)$ & $(0.024)$ \\
Democracy & 0.001 & $-0.004 * * *$ & $0.007 * * *$ \\
\multirow{3}{*}{ GNI per capita } & $(0.001)$ & $(0.001)$ & $(0.001)$ \\
& $-0.479 * * *$ & $0.101 * * *$ & $0.267 * * *$ \\
GNI growth & $(0.010)$ & $(0.003)$ & $(0.012)$ \\
& $0.002 * * *$ & 0.000 & $-0.001 * *$ \\
Domestic Conflict & $(0.001)$ & $(0.000)$ & $(0.000)$ \\
\multirow{2}{*}{ Oil } & $0.018 * * *$ & -0.003 & $-0.021 * *$ \\
& $(0.006)$ & $(0.003)$ & $(0.009)$ \\
Ethnic Fractionalization & $1.116 * * *$ & $-0.510 * * *$ & $-0.870 * * *$ \\
& $(0.272)$ & $(0.058)$ & $(0.121)$ \\
N & $0.441 * * *$ & $-0.062 * * *$ & $-0.290 * * *$ \\
\hline
\end{tabular}

Two-tailed tests. $* \mathrm{p}<0.10, * * \mathrm{p}<0.05, * * * \mathrm{p}<0.01$

Time trend variable (calendar year) included, but not reported. 